\title{
RECENT TRENDS IN THE STUDY OF MERGERS AND ACQUISITIONS
}

\author{
Sorin Adrian Achim
}

\section{Introduction}

In the present globalized world, investments play a key role. But the international financial crisis has affected both the course of these flows and their intensity. Investors have reconsidered their positions and strategies on the market. There are more options for investors to place their money and to develop. Out of these options, an important part of the investment flows happens through mergers and acquisitions. This is not necessarily linked to the number of such processes taking place, but it is more related to the sums of money that are transacted in merger and acquisition operations.

As Ferreira et al [10] point out, this type of operations has become an important instrument for activity internationalization. This aspect was emphasized in the field's literature from the beginning of this millennium. Consequently, different cultural, economic, social and legal environments meet. This is a very important feature of the mergers and acquisitions that, incorrectly treated, could lead to the failure of such an operation.

But mergers and acquisitions also take place at a domestic level. Regardless of the geographical space in which they occur, there are several goals in merging with or acquiring another company. Some of the most important are related to:

- overcoming legal barriers for entering a national market,

- access to resources,

- cheaper work force,

- enforcing the position on the market,

- lowering competition, etc.

Mergers and acquisitions are complex processes that, as shown earlier, need to be very well understood and planned in order to be successful. From here comes the need for continuous knowledge about the field's literature. However, the field's literature is wide and a lot of time would be needed for consulting all the information on the market. As shown in the Statistics part, when checking the Web of Knowledge platform, more than 200 articles were found with the specific subject of mergers and acquisitions only in 2014. To ease the work of researchers and practitioners in the field, the goal of this article is to present the latest trends in the study of mergers and acquisitions through a brief literature review of the papers published in 2014. This comes to complete the work of others who reviewed the mergers and acquisitions literature for different periods of time. In this respect it is noteworthy to mention the work of [10] who point out the evolution of the subjects treated by authors in the field's literature. Additionally, they present the most cited papers in order to show newcomers in this field of mergers and acquisitions research where to start from.

Our study is an update of such papers, allowing for an easier approach of the latest trends in mergers and acquisitions and their study.

The following part presents the methodology used.

We then present some statistics related to the articles published on the subject of mergers and acquisitions in 2014, based on what we found on the Web of Knowledge application. We point out that most of these studies are related to developed economies such as the USA, the UK, Germany or China. On the 2010-2014 ranking the first two developing countries that appear in the ranking are South Korea on the $12^{\text {th }}$ place and Romania on the $18^{\text {th }}$. For the 2014 ranking South Korea is on the $13^{\text {th }}$ place and Chile on the $20^{\text {th }}$. Consequently, we emphasize the need for more studies on mergers and acquisitions related to developing economies. In both cases, most of the researches in this field were published in Journal of Corporate 
Finance. Other features are assessed and presented in this part.

Some of the most important ideas found in the field's literature are then reviewed, summarized and briefly described in order to help researchers in the process of literature review. The emphasis is put on the banking sector as from this started the 2008 financial crisis and it is the most common in the latest field's literature.

Conclusions are drawn from our analysis and the most important directions in the study of mergers and acquisitions are emphasized.

\section{Methodology}

To achieve our goal we have accessed the Web of Knowledge database and considered all published works that satisfied the searching key "merger* and acquisition". These works were related to the economic field. However, as we speak about latest trends in the domain, we have filtered the results based on the year of publication, taking into consideration papers published in 2014.

The final sample is made up of 206 scientific researches that dealt with the issue of mergers and acquisitions in 2014 and were already available in the Web of Knowledge database at the time of our research. The final date for consulting the database was November, $20^{\text {th }}, 2014$.

First of all, we have descriptively analyzed the papers using the database's analyzing results option. Then we have proceeded in reading the papers and grouping them according to their main subject, in order to be able to construct a good quality review related to the latest trends in the field.

Additionally, we have also run a result analysis for the articles that satisfied our searching key, but for the 2010-2014 period. The reason is that 2010 is the year when the analysis in the study of [10] stops and we wanted to see what happened afterwards. In this part of the analysis were evaluated 1595 records.

Several hypotheses were constructed at the beginning of our analysis:

$H_{1}$ : Most of the studies in this field are related to the developed countries.

This hypothesis comes from the fact that the major part of the research in any field is related to developed countries, as they have the necessary tools for research and development.
Additionally, companies with the head quarter in developed countries are the ones that acquire.

$\mathrm{H}_{2}$ : The major part of the studies that deal with mergers and acquisitions are published in Management journals, or belong to the Management category.

This assumption comes from the fact that the managerial group of a company is the one to plan a merger or an acquisition and to conduct such a process, both a priori and post operation, including all the negotiation discussions. Managers are appointed by shareholders to represent their interest - profit.

However, papers of this kind can also belong to the category of corporation studies, as these are the ones that appeal to such operations.

$H_{3}:$ An important part of the sample deals with cross-border investigations.

We base this hypothesis on the fact that crossborder mergers and acquisitions are much more important than the domestic ones, as their impact internationally is more intense.

We also expect a lot of studies published lately to deal with:

- new ways of assessing the merger and acquisition process,

- the Euro Area crisis and its impact upon the merger and acquisition market,

- assessment of this issue in the banking sector, as this was the most affected by the bankruptcy of the Lehman Brothers Bank in the USA, and so on.

The reason for choosing the Web of Knowledge database is that it is the most important one internationally. The best journals and the best publishing houses have their papers gathered in this database. We have built our study on the presumption that, who is not in the Web of Knowledge, does not exist.

\section{Describing the Features of the Analyzed Sample}

In 2014, up to the moment of our analysis, 206 studies satisfied the searching key "merger* and acquisition*”. In order to understand the trends, we have chosen first to evaluate these studies using the "Analyze results" option of the Web of Knowledge database.

Based on these results, the first assumption is correct - almost all the studies in this group are related to the developed countries. The 
absolute supremacy belongs to the USA, to which are related 90 of the 206 studies, representing almost $44 \%$ of the sample. At an extremely high difference comes the United Kingdom, placed the second in the ranking, with a share of $13.1 \%$ (27 studies). Germany is on the third place, with 21 papers $(10.2 \%$ of the sample). The rest of the countries have relative frequencies lower than $8 \%$. Among them are: the Netherlands, Canada, France, China, Italy, Japan, and so on. This is an important aspect emphasized by this research - studies assessing the issue of mergers and acquisitions in the developing countries are scarce. This is a negative point in the study of such processes as, usually, one of the parts is located in such an economy. Thusly, more efforts should be directed towards evaluating features of mergers and acquisitions in the developing countries. An important matter is that these countries may be characterized by legal, social or economic instability, which change the typical development of such a process.

More than half of the sample (127 studies, representing $61.7 \%$ ) were studies published in the field of Economics. Thusly, from the point of view of the category, hypothesis 2 is rejected. Studies published in the Management category come only on the third place as a share, after the ones in Business Finance, as presented in Fig 1. If the category of Operations Research Management Science is added to Management, it comes on the second place, with a share of around $38 \%$ in the volume of the sample.

\section{Fig. 1: Bar chart of the most important categories to which the studies belong}

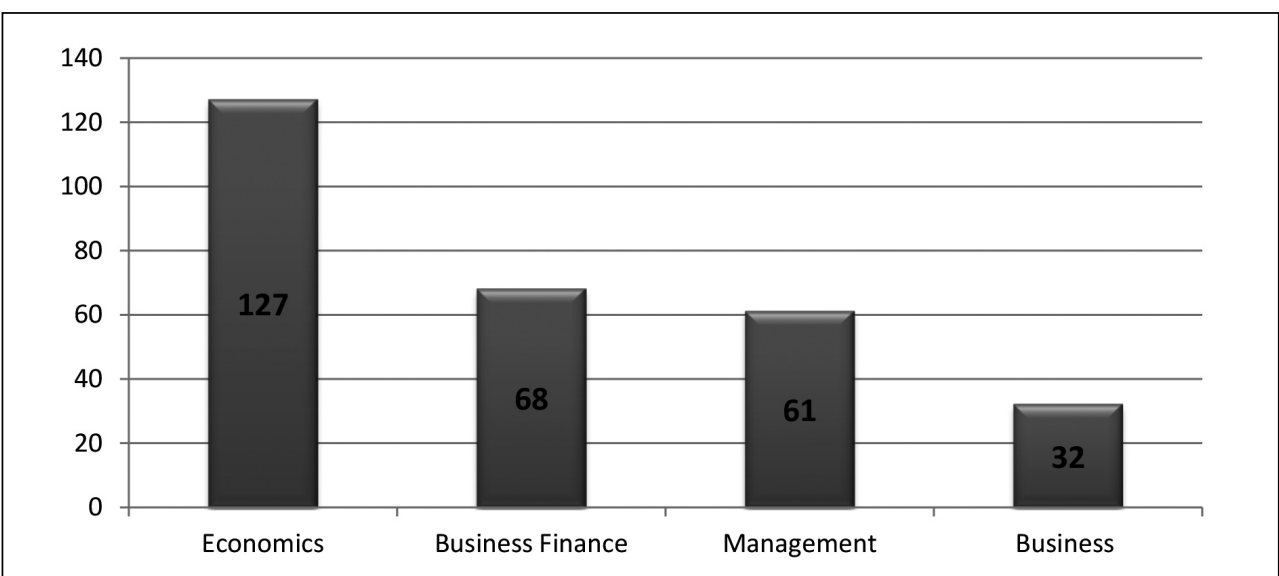

Source: own construction based on Thomson Reuters Web of Knowledge data

Hypothesis 2 is accepted when assessing the type of journal. Most of the researches in this field where published in 2014 in management journals or in the ones related to corporations or competitiveness. Differences in this respect are not that significant as in the case of the other characteristics analyzed. Most of the studies, 9, appeared in the Journal of Corporate Finance. Then comes Journal of Competition Law and Economics (8 papers). On the third place are five journals, each of them with 6 articles on this subject. These are:
- Strategic Management Journal,

- Review of Industrial Organization,

- Journal of Financial Economics,

- Journal of Finance,

- Journal of Banking and Finance.

They are followed by other management journals.

Hassan I. is the author with the most papers on mergers and acquisitions published in 2014.

As the study of [10] stopped in 2010, we also present a brief statistical description for the period 2010-2014. Out of the 1595 papers 
satisfying our searching criteria, 25\% were published in 2011. Fig. 2 shows that there are not important differences, except for 2014. This could come from the fact that, at the moment of the analysis, not all journals had their last issue published.

\section{Fig. 2: Structure of the studies published on mergers and acquisitions based on the year of publication}

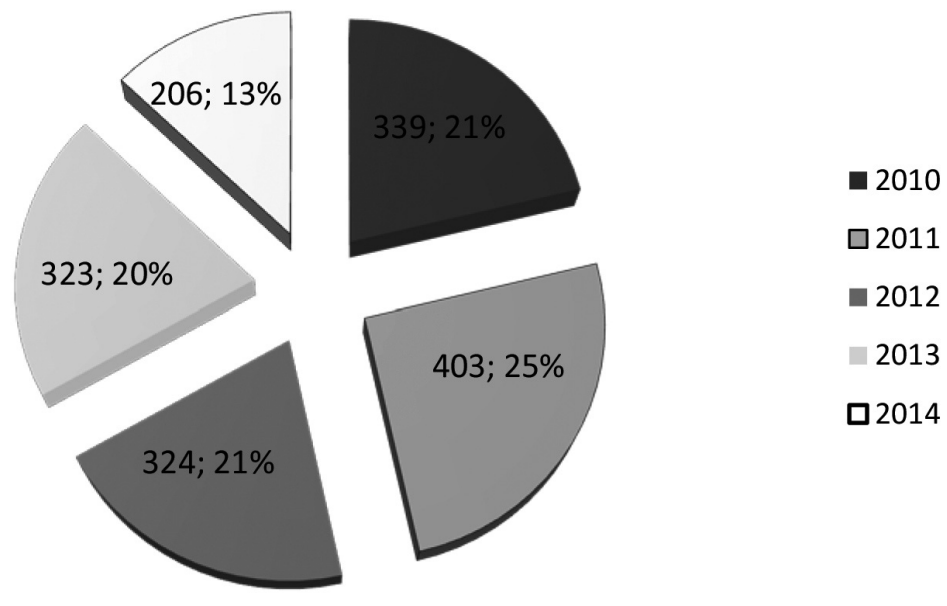

Source: own construction based on Thomson Reuters Web of Knowledge data

However, except for 2011, one can see an approximately constant number of articles published on this matter from 2010 towards present.

In what regards the country to which the paper is related, nothing changes for the first two ranks. The USA is on the first place for the entire period, too. Almost $40 \%$ of the sample is related to this country. The United Kingdom comes the second, again, with a very low share in respect to the USA (almost 11\%). Germany comes on the fourth place, being replaced by China on the third. We present the first 10 countries in Fig. 3. It can be seen that the first working hypothesis is also accepted for the 2010-2014 period. It is noteworthy to emphasize that there are 26 papers evaluating this issue in relation to Romania (it ranks $18^{\text {th }}$ ).
Only South Korea is to be found in more studies (42). All other developing economies are far lower in the ranking. For example Greece, which was extremely intensely affected by the global economic crises is to be found only on the $25^{\text {th }}$ place, with 19 studies in this field.

Most of the studies were published by Weber Y. and Tarba S.Y. (each one with 10 papers in this field in the analyzed period).

Journal of Corporate Finance is in the top of the ranking, again, with 49 articles. This time, between it and the Journal of Competition Law and Economics (46 papers) is placed the Review of Industrial Organization (48).

In what regards the category, Management and Business Finance switch places, with 595 and 480 studies, respectively. The first remains the Economics category. 


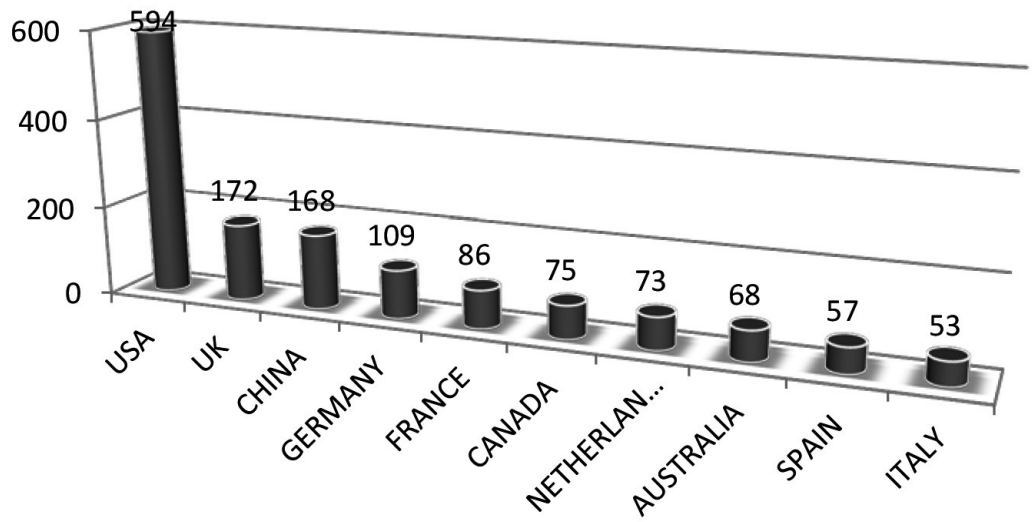

Source: own construction based on Thomson Reuters Web of Knowledge data

\section{The 2014 Trends in the Study of Mergers and Acquisitions}

Subsequent to reviewing the whole sample, we grouped the studies based on their main subject. In the following we briefly present some of the most important of our findings.

After evaluating the 2014 papers, we can conclude that the third working hypothesis is accepted. Most of the studies assess this issue from the point of view of cross-border transactions. A possible explanation is the fact that international transactions are of a much more interest than the domestic ones. Inside country mergers and acquisitions are of more interest only for the national actors on that market. Consequently, in order to be published and cited, authors seek to choose subjects that are of international, global relevance. When looking for the "cross-border" expression in the sample analyzed, more than 30 researches were found. This represents about $15 \%$ of the studies reviewed. However, much more of them really assess this issue from an international point of view. Few are the articles or other papers that have the subject related to domestic mergers and acquisitions. Among them we found, for example, the study of [25] that speaks about the problem of local governments' consolidation in
Japan. The article points out that governments receiving larger sums of money from the center are not likely to merge. Other examples of this type are related to the US newspaper market [16], the US banking sector [8] and so on. We have also found an example from a European country - the Netherlands. [4] study the spatial clustering process that appeared due to mergers and acquisitions in the Dutch banking sector. They analyze a very long period of time, from 1850 to 1993.

The field's literature also speaks about merger waves and their characteristics. This theory is to be found in relation to different sectors. For example, [31] estimate a model for the US banking sector for a large period (1987 to 2013) in order to test the theory of merger waves and find the causes for such waves. They emphasize that these are directly related to stock market booms. Merger waves are also assessed from the point of view of connections and linkages between industries. The influence of the development of the insurance market upon the hospital merger wave in the 1990s is evaluated by [30]. Waves of consolidation are also assessed in the insurance sector alone (see, for example, [34]). Mergers and acquisitions are expected to happen in order 
to restructure and consolidate the European insurance sector after the harmonized Solvency II framework that is about to be put into practice.

An important study comes to emphasize the growing significance of companies from emerging economies in the M\&A process ([29]). They point out that an important feature of the present M\&A wave is the influence of employees on the results of the process. These results were obtained through a laboratory experiment and, beside the growing importance of the companies' size, they also emphasize the increasing weight of the cultural issues in the mergers and acquisitions. Other studies come to point out the growing importance of cultural-based strategies. This is a trend in the study of corporate governance. A well developed cultural strategy increases the post acquisition performance and efficiency [21]. Additionally, [36] stress the need for considering cultural differences when constructing the M\&A strategies. The performance of mergers and acquisitions cannot be anymore explained in a simple manner. Another aspect treated by this study is the importance of the managerial team upon the M\&A efficiency. [2] also assess cultural issues. Their result is that M\&A success is directly related to cultural fit. A new approach is introduced by [12] - learning by observing. They show that culturally different companies can merge or be involved in an acquisition process in a more efficient way by studying the problems encountered by their predecessors on a specific market. Problems related to spatial and cultural distance are also present in other newly published studies (see, for example, [24]).

An increasing importance is given nowadays to the evaluation of intermediaries in the mergers and acquisition processes. The most frequently of such groups treated in the latest literature are:

- Managers,

- Accountants and auditors,

- Financial advisors.

Their role is very important as what finally counts is the performance of the M\&A process and the gains that this process brings to shareholders. Performance, in general, is assessed in relation to board features (see, for example [28]). The latest studies also evaluate the performance of the M\&As in relation to the managers' characteristics. For example, [17] investigate the influence of CEOs experience upon the M\&A performance. They conclude that firms with former investment directors in the managerial team have a higher propensity to acquire and are more efficient in this process. On the contrary, more traditionalist companies, with conservative managers are, are less likely to get involved in M\&A operations [19]. This statement is true, even though CEOs in the acquirer company are more likely to have increased compensations after the acquisition [18].

Financial advisors are also very important, especially when they have experience in the target country, while the acquirer does not. Studies such as the one of [13] confirm the certification hypothesis in the choice of consultants for cross-border M\&A.

Traditional companies as mentioned before also have conservative accounting approaches. Consequently, more traditional firms from the accounting point of view are much more reluctant towards mergers and acquisitions. Post merger accounting issues are also discussed in the newest literature. [6] emphasizes the difference between pre and post transaction values of assets and evaluates the diversification discount. It is interesting to see how the whole process of accounting standardization based on the IFRS has affected M\&A performance. [5] state that the merger premium has decreased due to international harmonization of reporting standards.

Beside accountants, auditors also play a key role in the M\&A process. This aspect is brought into light by [23] who show a significant decrease in the costs the acquirer has to bear when a Big $\mathrm{N}$ auditor is auditing its target company. But due to increased market power and to the Big $\mathrm{N}$ theory, the auditing market is also subjected to M\&As. The impact of them is assessed in the field's literature. Studies on this subject reject the hypothesis of market concentration upon auditing fees [22]; [9].

\subsection{The Banking Sector}

The banking sector is highly assessed in mergers and acquisitions problems. Out of the 206 papers in the sample, 23 deal specifically with this sector. Consequently, more than $10 \%$ of the sample is related to the banking sector. It is no wonder that the Journal of banking and Finance is among the top in the ranking based on the number of articles published on the subject of mergers and acquisitions.

In this group of papers appear more mergers and acquisitions related theories. There are 
several theories related to the size of the banks involved, to the size of the banking sector and to changes that appear on the market once with the consolidation through M\&A. We restate the paper of [31] that comes with an interesting theory - "too big to merge?".

Related to it is another study that tests the idea of "too big to succeed" [27]. The authors of this study use a sample of Japanese bank mergers to test the effect of sectorial consolidation upon financial performance. It is true that the consolidation process brings along more market power, by the profit and cost efficiency are very little affected. This effect is more intense when mergers and acquisitions of banks are the result of governmental influences in post crisis economies. In opposition, [33] show that public banks perform more badly then private ones only when they are forced to purchase other banks with major problems. Otherwise, after mergers or acquisitions with normal banks that have insignificant problems or no problems at all, they have the same results as the private banks.

The issue of crises appears in other studies related to M\&A in the banking sector, too. For example, the financial crisis at the beginning of the Millennium caused a concentration of the Turkish banking sector (due to liquidations and M\&As) and the development towards a monopolistic market [37], [32]. On the contrary, the consolidation of the Spanish banking sector after the 2008 financial crisis had little impact upon costs for the clients [26]. [7] explain that the resemblance between the Euro Area and the Latin America crises and the difference from the Asian one is due to the fact that one of the most important aspects was attaching much more weight to bank mergers than to labor force mobility as adjustment mechanism. A novelty in this field is the study of [3] that develops and early-warning model for the prediction of problems in the European banking sector using both micro and macro-level data. The analysis is run on the data of the present financial crisis.

In contrast with the first two theories presented above comes the "too big to fail" approach. This theory is found not only in the banking sector, but also in insurance and others [11]. [11] study this effect on the US market for the 2001-2011 period and show that there is not clear evidence of it, but that the characteristics of the acquirer are, however, important. These characteristics are associated with different risks that can appear in the M\&A process and after it.

Another hypothesis is to be found in the field's literature lately is the "concentrationfragility" one. In [38] it is tested along with the systemic risk and confirmed based on a sample of domestic and cross-border mergers.

The level of concentration and consolidation is also of interest from the point of view of evaluating it. That is why [14] constructed indexes to measure the level of market concentration in the banking sector. These indexes could also be transposed in other sectors, too. They also evaluate the influence of market concentration upon the corporate cash holdings.

The Data Envelopment Analysis (DEA) is respecified by [15] in the form of an inverse DEA to assess the efforts that the acquirer or a merger has to make in order to reach a certain level of efficiency of the process.

There are other studies that evaluate the pre and post M\&A situation. For example, [1] show that, as pre-M\&A process equilibrium is altered, effects are different for the parties involved in the process, the economic sector and households. A merger in the banking sector facilitates access to credit for companies, but reduces it for households. [35] study these aspects on the Malaysian banking market. Their results are consistent with the fact that the acquirer is more productive in respect to its targets, thing that insures its position in the negotiation process. Efficiency of bank mergers in Taiwan is also given by shareholders [20]. The dynamism of such processes is investigated and persistent and intertemporal effects evaluated.

\section{Conclusions}

The goal of our study was to present the latest trends in the study of mergers and acquisitions. Analyzing descriptively the studies published in 2014, in particular, and the ones published in the period 2010-2014 in general, we have pointed out that a significant majority of them are related to developed countries. This is extremely important, as, usually, one of the parts in a merger or acquisition process is located in a developing country. Consequently, there is an important need in the field's literature to assess this issue from the point of view of the less developed part. Almost all researches do this from the point of view of the more developed, more powerful partner in the process. Researchers have to bear in mind 
the fact that different countries have different characteristics. What is suitable for one of them may not be the best for another. There are many examples in Economics that not all results for developed countries can be $100 \%$ transposed to the developing ones. For example, the relation described by the Phillips curve is not valid for many developing countries.

Changes in the approach would also be benefic for companies that want to extend to developing economies. In this way they would have a better possibility to inform about the features of a certain national market and then plan their actions according to them.

Additionally, most of the researches deal with cross-border issues related to mergers and acquisitions, including financial intermediaries that could get involved in such processes. We think that domestic evaluation of mergers and acquisitions should be encouraged, as specificities of local markets could be found out of such investigations.

Merger waves and the banking sector occupy an important part of the literature assessing mergers and acquisitions. For each of the two, we pointed out the latest approaches and studies. For example, we emphasize the appearance of new indexes that evaluate M\&A efficiency or the level of consolidation of a market.

The role of intermediaries in M\&A processes is also more and more assessed. And here we speak about accountants, auditors or financial advisors.

After reviewing the latest trends in the study of mergers and acquisitions based on the most recently published papers we suggest potential authors to start approaching other sectors than the banking one, too. This because each sector has its own specificities that may be extremely different, but also extremely important.

Due to the limits of such a paper, we do not consider our study exhaustive. Complements to it can be brought and are highly encouraged.

\section{References}

[1] BARROS, P. P., BONFIM, D., KIM, M. and MARTINS, N. C. Counterfactual analysis of bank mergers. Empirical Economics. 2014, Vol. 46, Iss. 1, pp. 361-391. ISSN 1435-8921. doi: 10.1007/s0018101206661.

[2] BAUER, F. and MATZLER, K. Antecedents of M\&A Success: The Role of Strategic Complementarity, Cultural Fit, and Degree and
Speed of Integration. Strategic Management Journal. 2014, Vol. 35, Iss. 2, pp. 269-291. ISSN 0143-2095. doi:10.1002/smj.2091.

[3] BETZ, F., OPRICA, S., PELTONEN, T. A. and SARLIN, P. Predicting distress in European banks. Journal Of Banking \& Finance. 2014, Vol. 45, Iss. August, pp. 225-241. ISSN 03784266. doi:10.1016/j.jbankfin.2013.11.041.

[4] BOSCHMA, R. and HARTOG, M. Merger and Acquisition Activity as Driver of Spatial Clustering: The Spatial Evolution of the Dutch Banking Industry. Economic Geography. 2014, Vol. 90, Iss. 3, pp. 247-266. ISSN 0013-0095.

[5]BOZOS, K., RATNAIKE, Y.C., ALSSHARAIRI, $M$. How has the international harmonization of financial reporting standards affected merger premiums within the European Union? International Review of Financial Analysis. 2014, Vol. 31, Iss. January, pp. 48-60. ISSN 1057-5219. doi:10.1016/j.irfa.2013.09.004.

[6] CUSTODIO, C. Mergers and Acquisitions Accounting and the Diversification Discount. Journal of Finance. 2014, Vol. 69, Iss. 1, pp. 219240. ISSN 0022-1082. doi:10.1111/jofi.12108.

[7] EICHENGREEN, B., JUNG, N., MOCH, S., MODY, A. The Eurozone Crisis: Phoenix Miracle or Lost Decade? Journal of Macroeconomics. 2014, Vol. 39, Part: B., Iss. March, pp. 288-308. ISSN 0164-0704. doi:10.1016/j. jmacro.2013.08.005.

[8] van EWIJK, S. E. and ARNOLD, I. J. M. How bank business models drive interest margins: evidence from US banklevel data. European Journal of Finance. 2014, Vol. 20, Iss. 10, Special Issue: SI, pp. 850-873. ISSN 1351847X.

[9] FERGUSON, A., PUNDRICH, G. and RAFTERY, A. Auditor Industry Specialization, Service Bundling, and Partner Effects in a Mining Dominated City. Auditing - A Journal of Practice \& Theory. 2014, Vol. 33, Iss. 3, pp. 153180. ISSN 0278-0380. doi:10.2308/ajpt50728. [10] FERREIRA, M. P., SANTOS, J. C., RIBEIRO de ALMEIDA, M. I. and REIS, N. R. Mergers \& acquisitions research: A bibliometric study of top strategy and international business journals, 1980-2010. Journal of Business Research. 2014, Vol. 67, Iss. 12, pp. 2550-2558. ISSN 0148-2963.

[11] FILSON, D. and OLFATI, S. The impacts of Gramm-Leach-Bliley bank diversification on value and risk. Journal of Banking \& Finance. 2014, Vol. 41, Iss. Arpil, pp. 209-221. ISSN 0378-4266. doi:10.1016/j.jbankfin.2014.01.019. 
[12] FRANCIS, B.B., HASAN, I., SUN, X. and WAISMAN, M. Can firms learn by observing? Evidence from crossborder M\&As. Journal of Corporate Finance. 2014, Vol. 25, Iss. April, pp. 202-215. ISSN 0929-1199. doi:10.1016/j. jcorpfin.2013.11.018.

[13] FRANCIS, B. B., HASAN, I. and SUN, X. The certification role of financial advisors in crossborder M\&As. International Review of Financial Analysis. 2014, Vol. 32, Iss. March, pp. 143-158. ISSN 1057-5219. doi:10.1016/j. irfa.2014.01.003.

[14] FRANCIS, B. B., HASAN, I. and WANG, $H$. Z. Banking deregulation, consolidation, and corporate cash holdings: US evidence. Journal of Banking \& Finance. 2014, Vol. 41, Iss. April, pp. 45-56. ISSN 0378-4266. doi:10.1016/j. jbankfin.2013.12.018.

[15] GATTOUFI, S., AMIN, G. R. and EMROUZNEJAD, A. A new inverse DEA method for merging banks. IMA Journal of Management Mathematics. 2014, Vol. 25, Iss. 1, pp. 73-87. ISSN 1471-678X. doi:10.1093/imaman/dps027. [16] GENTZKOW, M., SHAPIRO, J. M. and SINKINSON, M. Competition and Ideological Diversity: Historical Evidence from US Newspapers. American Economic Review. 2014, Vol. 104, Iss. 10 , pp. 3073-3114. ISSN 0002-8282. doi:10.1257/aer.104.10.3073.

[17] HUANG, Q. Q., JIANG, F., LIE, E. and YANG, $\mathrm{K}$. The role of investment banker directors in M\&A. Journal of Financial Economics. 2014, Vol. 112, Iss. 2, pp. 269-286. ISSN 0304-405X. doi:10.1016/j.jfineco.2014.02.003.

[18] ISHII, J. and XUAN, Y. H. Acquirer target - social ties and merger outcomes. Journal of Financial Economics. 2014, Vol. 112, Iss. 3, pp. 344-363. ISSN 0304-405X. doi:10.1016/j. jfineco.2014.02.007.

[19] KRAVET, T.D. Accounting conservatism and managerial risktaking: Corporate acquisitions. Journal of Accounting \& Economics. 2014, Vol. 57, Iss. 23, pp. 218-240. ISSN 0165-4101. doi:10.1016/j.jacceco.2014.04.003.

[20] LEE, T. H. and CHIH, S. H. Does Financial Restructuring Change the Relationship Between Corporate Governance and the Static and Dynamic Efficiency of Bank Mergers in Taiwan? Emerging Markets Finance and Trade. 2014, Vol. 50, Supplement:2, pp. 189-201. ISSN 1540496X. doi:10.2753/REE1540496X5002S213.

[21] LIN, L. H. Organizational Structure and Acculturation in Acquisitions: Perspectives of Congruence Theory and Task Interdependence.
Journal of Management. 2014, Vol. 40, Iss. 7, pp. 1831-1856. ISSN 0149-2063. doi:10.1177/0149206312442385.

[22] LIU, Y. Z. Should further mergers be allowed? Product differentiation and merger in the external audit market. Applied Economics. 2014, Vol. 46, Iss. 7, pp. 741-749. ISSN 00036846. doi:10.1080/00036846.2013.851777.

[23] LUYPAERT, M. and Van CANEGHEM, T. Can Auditors Mitigate Information Asymmetry in M\&As? An Empirical Analysis of the Method of Payment in Belgian Transactions. Auditing A Journal of Practice \& Theory. 2014, Vol. 33, Iss. 1, pp. 57-91. ISSN 0278-0380. doi:10.2308/ ajpt50590.

[24] MALHOTRA, S. and GAUR, A. S. Spatial geography and control in foreign acquisitions. Journal of International Business Studies. 2014, Vol. 45, Iss. 2, pp. 191-210. ISSN 00472506. doi:10.1057/jibs.2013.50.

[25] MIYAZAKI, T. Municipal consolidation and local government behavior: evidence from Japanese voting data on merger referenda. Economics of Governance. 2014, Vol. 15, Iss. 4, pp. 387-410. ISSN 1435-6104. doi:10.1007/ s1010101401456.

[26] MONTES, C. P. The effect on competition of banking sector consolidation following the financial crisis of 2008. Journal of Banking \& Finance. 2014, Vol. 43, pp. 124-136. ISSN 03784266. doi:10.1016/j.jbankfin.2014.03.004.

[27] MONTGOMERY, H., HARIMAYA, K. and TAKAHASHI, Y. Too big to succeed? Banking sector consolidation and efficiency. Journal of International Financial Markets Institutions \& Money. 2014, Vol. 32, pp. 86-106. ISSN 10424431. doi:10.1016/j.intfin.2014.05.005.

[28] MULLER, V.-O., IENCIU, I.-A., BONACI, C.-G. and FILIP, C.I. Board Characteristics Best Practices and Financial Performance. Evidence from the European Capital Market. Amfiteatru Economic. 2014, Vol. 16, Iss. 36, pp. 672-683. ISSN 1582-9146.

[29] OH, J. H., PETERS, L. D. and JOHNSTON, W. J. Who's acquiring whom? Experimental evidence of firm size effect on B2B mergers and marketing/sales tasks. Industrial Marketing Management. 2014, Vol. 43, Iss. 6 (SI), pp. 1035-1044. ISSN 0019-8501. doi:10.1016/j. indmarman.2014.05.016.

[30] PARK, M. and TOWN, R. Industry Shock Expectations, Interindustry Linkages, and Merger Waves: Evidence from the Hospital Industry. Journal of Economics \& Management 
Strategy. 2014, Vol. 23, Iss. 3, pp. 548-567. ISSN 1058-6407. doi:10.1111/jems.12067.

[31] POLEMIS, M. L. and PALEOLOGOS, J. $\mathrm{M}$. Too big to merge? Evidence from the US banking sector. Applied Economics Letters. 2014, Vol. 21, Iss. 11, pp. 782-785. ISSN 13504851. doi:10.1080/13504851.2014.889797.

[32] REPKOVA, I. and STAVAREK, D. Concentration and Competition in the Banking Sector of Turkey. Amfiteatru Economic. 2014, Vol. 16, Iss. 36, pp. 625-640, ISSN 1582-9146. [33] SHEN, C. H., HASAN, I. and LIN, C. Y. The Government's Role in Government-owned Banks. Journal of Financial Services Research. 2014, Vol. 45, Iss. 3, pp. 307-340. ISSN 09208550. doi:10.1007/s1069301301680.

[34] STOYANOVA, R. and GRUNDL, H. Solvency II: A Driver for Mergers and Acquisitions. Geneva Papers on Risk and Insurance Issues and Practice. 2014, Vol. 39, Iss. 3, pp. 417-439. ISSN 1018-5895. doi:10.1057/gpp.2013.32.

[35] SUFIAN, F. and HABIBULLAH, M. S. The impact of forced mergers and acquisitions on banks' total factor productivity: empirical evidence from Malaysia. Journal of the Asia Pacific Economy. 2014, Vol. 19, Iss. 1, pp. 151-185. ISSN 1354-7860. doi:10.1080/13547860.2013.818428.
[36] VAARA, E., JUNNI, P., SARALA, R. M., EHRNROOTH, M. and KOVESHNIKOV, A. Attributional Tendencies in Cultural Explanations of M\&A Performance. Strategic Management Journal. 2014, Vol. 35, Iss. 9, pp. 1302-1317. ISSN 0143-2095. doi:10.1002/smj.2163.

[37] VARDAR, G., AYDOGAN, B. and SEVEN, $U$. The Competitive Conditions of the Banking Industry in the Post-Crises Period: An Analysis of Turkish Banks. Iktisat Isletme Ve Finans. 2014, Vol. 29, Iss. 339, pp. 49-68. ISSN 1300610X. doi:10.3848/iif.2014.339.4013.

[38] WEISS, G. N. F., NEUMANN, S. and BOSTANDZIC, D. Systemic risk and bank consolidation: International evidence. Journal of Banking \& Finance. 2014, Vol. 40, pp. 165-181. ISSN 0378-4266. doi:10.1016/j. jbankfin.2013.11.032.

Assoc. professor Sorin Adrian Achim, Ph.D. Babeș-Bolyai University Cluj-Napoca Faculty of Economics and Business Administration Department of Acounting and Audit sorin.achim@econ.ubbcluj.ro 


\section{RECENT TRENDS INTHE STUDY OF MERGERS AND ACQUISITIONS}

\section{Sorin Adrian Achim}

Mergers and acquisitions are important operations that happen nowadays. The goal of such processes is to "conquer" new markets and benefit from their resources (natural or human), or to lower competition (by acquiring a competitor or merging with it). More and more studies are written on this subject, thing that makes people interested in it have a difficult job in staying up to date. That is why the present research had as a goal to evaluate and summarize the latest trends in the study of this subject. Based on our goal we have conducted an extended analysis on the studies published in 2014 in this field. Additionally, we have also descriptively analyzed the period 2010-2014. For this, we have presumed that the most important research is to be found in the ISIThomson Web of Knowledge. We point out the lack on such literature on the developing countries, as most of these studies are related to the developed ones, such as the USA, the UK, China or Germany. The major part of them is published in the Journal of Corporate Finance. The second part of the article comes to emphasize the most important ideas that are to be found in the 2014 field's literature. Many of the studies are related to the banking sector. Additionally, we found new indexes created to evaluate the M\&A performance or the concentration degree of the market due to and after M\&A operations. There are papers that assess different theories, such as the merger waves theory, the concentration-fragility hypothesis, the too-big-to-merge, too-big-to-succeed or, too-big-to-fail theories and so on.

Key Words: Mergers and acquisitions, research, trends, review.

JEL Classification: G34, M14.

DOI: 10.15240/tul/001/2015-1-010 